\title{
DYNAMIC OBJECTS GEOMETRY MEASUREMENT BY LASER SCANNING - A CASE STUDY
}

\author{
Andrzej Kwinta, Robert Gradka
}

\begin{abstract}
Summary
The objective of the study was to analyse of measurement of moving objects by means of the Total Station (TS) method and Terrestrial Laser Scanning (TLS). The subject of the tests was the "Polinka" gondola cable car over the Odra river in Wrocław. Research covered the basic and control measurements. The results of observations of suspension ropes' deflection of the cable car in kinematical state were compared for various degrees of loading. During the motion of the gondola, the shape of the pull and supporting rope is subject to constant shifts. TS measurements are restricted solely to registering interim positioning of the points of pull lines (measurement of static objects). Laser scanner measurements may reveal changes in the location of many points (i.e. drive lines, catenaries or carriages) within a unit of time. The tests were designed to show whether it is possible to capture the shifts in geometry of the moving object (mainly by means of the TLS methods - in the course of constant vibrating of lines and during the movement of gondolas). The analyses indicated that it is possible to capture the changes of geometry by means of the TLS method, however, upon strictly specified measurement conditions.
\end{abstract}

\section{Keywords}

laser scanning • objects' dynamics • monitoring geometry

\section{Introduction}

In the course of the movement of carriages, the sag of deflection of the pull cable changes. The actual shape of the dynamic cable is reflected by the image. Measurements made by means of Total Station are restricted to registering interim points of the cable, observed solely in the selected $i$-th target plane $\Phi_{\mathrm{i}}$ of the TS. In case of survey measuring, the scope for application of the results of such digitalization of lines depends on the type and plan of measurements, which might cover the following observations:

- $\quad$ synchronous (Fig. 1) - in selected planes $\Phi_{1}, \Phi_{2}$ in case of two TS, or in planes $\Phi_{1}$, $\Phi_{2}, \ldots \Phi_{\mathrm{N}}$ in case of the use of $N$ Total Stations. The outcome of synchronous measurements is an interim, geometric image of the cable, observed simultaneously on the subsequent planes $\Phi_{\mathrm{i}}$ at the time of passing by the gondola through the permanent target plane $\Phi_{1}$ or $\Phi_{2}$ of the selected TS. 


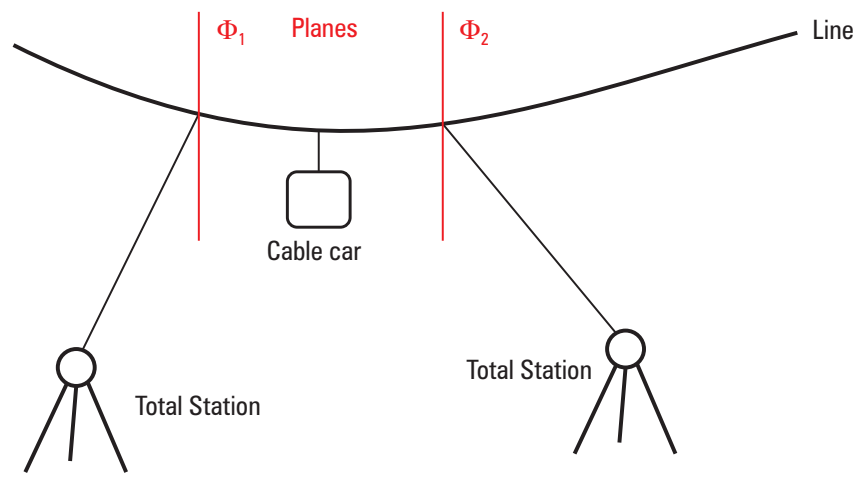

Source: Authors' own study

Fig. 1. Synchronous observations carried out in two Total Stations for two different planes (marked in red)

- non-synchronous (Fig. 2) - in selected, changing target planes $\Phi_{i}$, where $i=1,2,3$, $\ldots, n$ of one TS. The outcome of the observations is non-simultaneous - that is, $n$ selected, oriented target planes of Total Station is the image consisting of multiple interim locations (traces of material points) of the pull cable, observed during the moments of the gondola passing through these particular target planes.

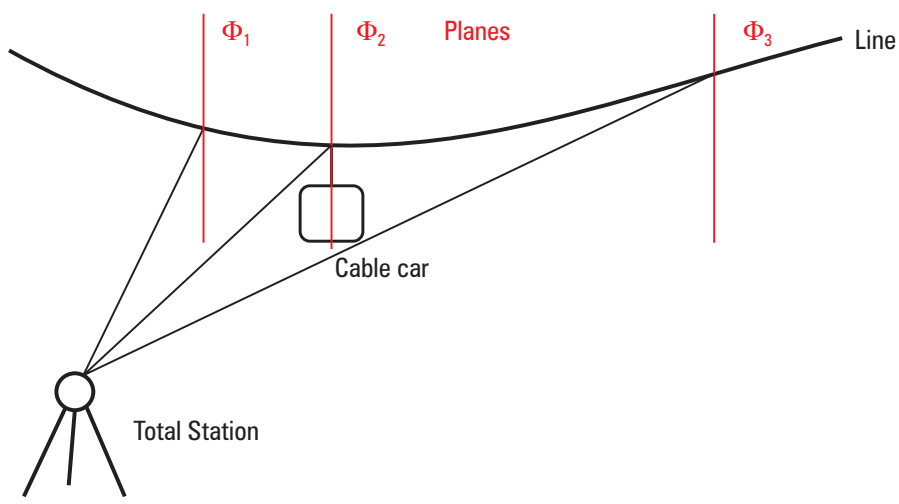

Source: Authors' own study

Fig. 2. Non-simultaneous observations carried out from one Total Station for each plane (marked in red)

Classical survey measurements make it possible to designate geometry of such objects as cable cars, however in order to obtain the sufficient precision, these objects remain immovable in the course of the measurement or they are tested under a fixed load on the same $\Phi_{\mathrm{i}}$ planes. Unfortunately this is not possible to reproduce for 
repeated analyses since the same plane can never be re-selected. It was thus decided that Total Station measurements of the pull lines would be conducted in selected points of these lines, and treated as control measurements for the Terrestrial Laser Scanning.

In contrast to survey measuring, the TLS method makes it possible to measure a large number of points in number $N$ of target planes $\Phi_{\mathrm{i}}$, in a short period of time and with diverse density of these points in a given plane. The basic advantage of laser scanning is a fast spectrum of application possibilities: from object visualization [Slob and Hack 2004, Buchroithner et al. 2009, Gikas 2012, Pilecki 2012, Tong et al. 2015], to architectonic inventory [Jones et al. 2009, Abmayr et al. 2012, Kraszewski 2012, Bernat et al. 2016], geometry measurements [El-Omari and Moselhi 2008, Corso et al. 2017, Kwinta et al. 2018], 3D documentation and mapping of sites and structures of archaeological and cultural heritage [Galeazzi et al. 2014, Quagliarini et al. 2017, Szafarczyk and Gawałkiewicz 2018, Jo and Hong 2019], to detailed measurements of structural changes, volume changes [Olsen et al. 2010, Rüther et al. 2013, Janowski et al. 2016, Zaczek-Peplinska and Kowalska 2016, Mill and Ellmann 2019] and deformation changes [Gordon and Lichti 2007, Kamiński et al. 2008, Soudarissanane et al. 2008, Choi et al. 2013, Bazarnik 2016, Xiangyang et al. 2017], landslide tests [Barbarella et al. 2013, Ghuffar et al. 2013, Pilecka and Manterys 2013, Barbarella et al. 2017,], mining engineering objects [Gawronek et al. 2016, Janowski et al. 2016, Buczek et al. 2018], or reverse engineering [Uchański and Soerensen 2010, Herráe et al. 2016, Roca-Pardiñas et al. 2017]. However, these objects are normally in static condition. Also, insufficiency of tests related to the possibility of applying and using TLS technology for determining the geometry of moving objects [Jackson et al. 2019, Mill and Ellmann 2019] convinced the authors to conduct tests in this scope, bearing in mind two significant assumptions to the applied method:

- the carriages will be in motion - without the necessity to stop them,

- in the course of conducting the measurements, the load of gondolas changes (carriages loaded with passengers in different numbers).

\section{Object characteristics}

The object, which has been subjected to tests, is a year-round gondola cable car called "Polinka" (Fig. 3) in the city of Wrocław. It has been in operations since 2013, over the river Oder, connecting the main campus of the Wrocław University of Technology and the building of Geocentrum, located on the other side of the river. This is a type of aerial cable car, consisting of two carriages, suspended on two carrying-hauling lines. The cabins move in the opposite directions with a speed of up to $5 \mathrm{~m} / \mathrm{s}$, and they are connected through a drive cable, whereas the pull cable is immobile. Each wagon may accommodate up to the maximum of 15 persons and the maximum capacity amounts to 366 persons per hour in both directions [https://pl.wikipedia.org/wiki/ Kolej_gondolowa_„Polinka”_we_Wrocławiu, https://visitwroclaw.eu/miejsce/polinkawroclaw]. 


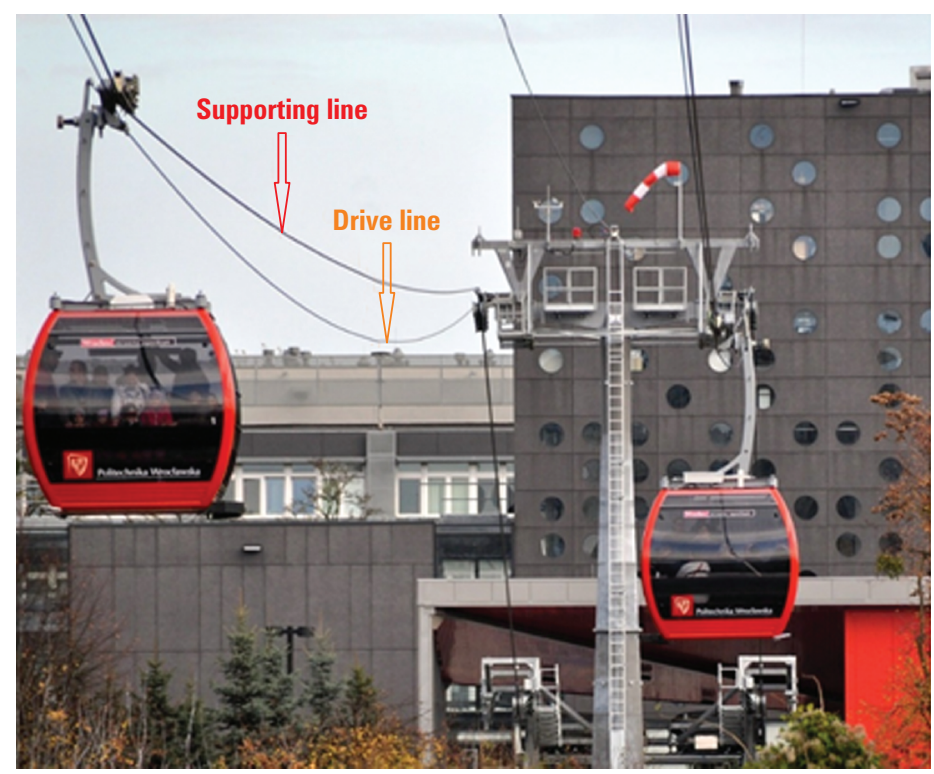

Source: Authors' own study

Fig. 3. "Polinka" gondola cable car (view of the wagons in motion, route support, and northern station)

This cable car is built in accordance with the binding provisions of the Polish law [The Ordinance... 1998], whereby the construction elements of cable cars consist of:

- station buildings,

- route supports,

- foundations:

- drive, winding, and tensioning systems,

- route supports.

The line is 373 meters long, of which the majority is located in between the route supports (the distance between them in a straight line is approx. $264 \mathrm{~m}$ ). The journey from one station to another takes ca. 2 minutes.

\section{Measurement grid and methodology of the tests}

The tests entailed the measurement of carrying ropes of the gondola cable car at two stages, by means of two methods:

- via Terrestrial Laser Scanning - during motion of the carriages upon variable load - as the basic measurement in variable atmospheric conditions,

- via Total Stations - during standstill of the carriages at stations - as the control of measurement correctness of carrying ropes by the laser scanner. 
Both measurements were based on the measurement grid (Fig. 4) assumed for the purposes of conducting the observations - by means of GNSS Receiver Trimble R8 - via RTK method. Each of the points of the measurement grid was permanently stabilized by means of a special nail with concrete - inside the concrete or in concrete slabs, as well as being measured by means of GNSS receiver for at least 60 seconds at $1 \mathrm{~s}$ intervals. The points of the grid were established in the second, independent measurement using RTK method, upon re-initiation of the receiver via classical method - Total Station. The mean error of horizontal location amounted to $\pm 20 \mathrm{~mm}$, and of vertical location, $\pm 20 \mathrm{~mm}$. Five points were established for the conduct of this tasks, but the total of 3 points were assumed for measurements and subsequent calculation (marked P2, P3, P6) - the remaining two served as spare points (Fig. 4).

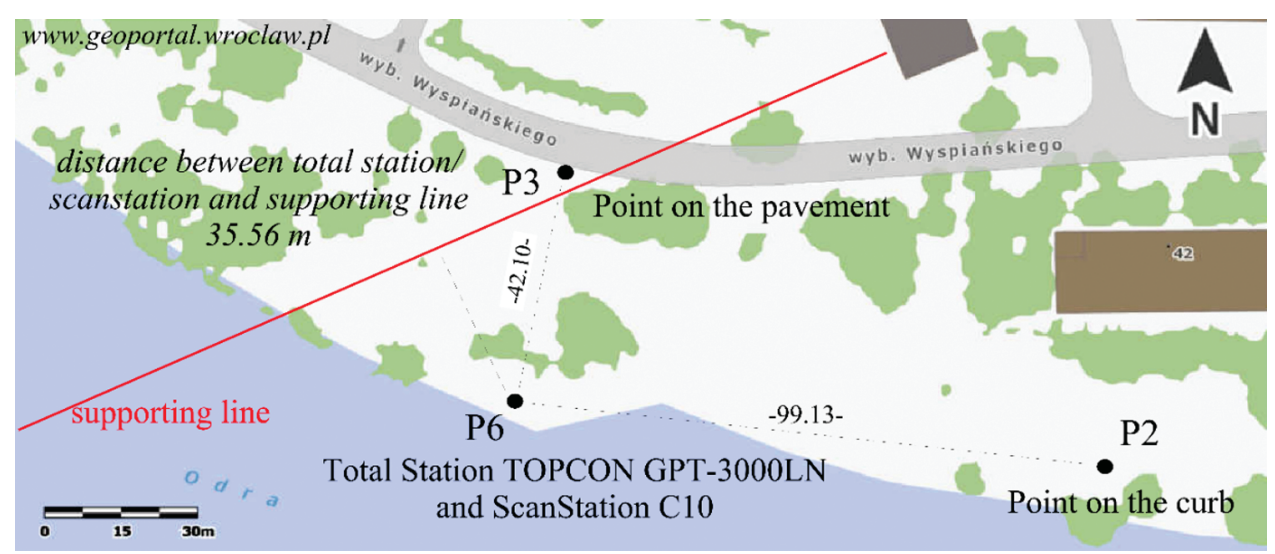

Source: authors' own study based on the map from www.geoportal.wroclaw.pl

Fig. 4. The measurement grid was permanently stabilised (northern station marked with a grey square)

While preparing for the conduct of the experiment consisting of measuring via laser scanner of the ropes of cable car in motion, the authors decided that the grid would be designed and determined in such a way so that it enables measurement solely of the section of ropes in the cable car and not its entirety, bearing in mind the test nature of the tests conducted. The fact that the assumed grid was located solely on one riverbank constituted an additional impediment, due to:

- lack of possibility of entering an inaccessible area located on the other side of the Oder river (from the side of the southern station),

- preventing the assembly of the grid and the measurement itself - area-related obstacles occurring in the form of i.e. tree crowns (northern side), but also dense bushes and trees located directly by the river bank (southern side),

- very broad river bank in relation to the length of cable car, which decreased the surface for the assembly of the grid, 
- the best visibility of the tested object and a relatively small distance from the stands of instruments for the lines located in the central part of the cable car (between the supports), where the largest load of carrying lines lies and the biggest deflection bend occurs.

The location of TS and the laser scanner shared the same spot within the grid, marked with P6 (Fig. 4). Both instruments were tied subsequently to the marked points $\mathrm{P} 2$ and $\mathrm{P} 3$.

After the setting and calculating the measurement grid, the carrying lines were measured by means of TOPCON GPT-3000LN Total Station. Reflectorless, non-synchronous measurement covered 39 points located on both ropes of the cable car at the length of approx. $160 \mathrm{~m}$ of the entire cable car. Importantly, the measurement was carried out during the standstill of the wagons on stations, and in favourable weather conditions - windless or with minimum wind. During the measurement of carrying lines certain difficulties were encountered, preventing the measurement of points on pull lines, due to:

- lack of possibility to precisely target the rope - from a large distance, the rope is too thin, even upon large magnification of the telescope,

- small motions and swinging of the ropes - due to weaker / stronger gusts of wind,

- small incidence angles of laser radius towards the lines - the smaller the angle, the smaller the scope,

- restrictions related to the texture of the rope - the smoother the texture, the larger the scope,

- dark colour of the rope - decreasing the scope,

- possible dampness of the surface of the lines, as well as larger humidity of air above the river (the ropes are located directly above it),

- air masses varying in temperatures above the water and above the concrete surface [Lenda 2005, Klimkowska and Wróbel 2006].

All the above impediments directly impacted the scope of the device itself. The reflected laser beam was impossible or too time-consuming to achieve, and thus the non-precise reading of distances by the instrument was possible.

Measuring via TLS took place directly after the TS measurement, in two stages, in windless conditions. The experiment was conducted using Leica C10 laser scanner, by means of which two point clouds were registered (for different weather conditions), consisting jointly of over one million points (before filtration), with the assumed density of points of $5 \mathrm{~mm} \times 5 \mathrm{~mm}$. The measurement covered fragments of carrying lines, drive lines, cable car arm and the wagons.

Prior to conducting the measurement proper, the authors carried out a density test on a very short section of the cable car in order to select the optimal value for this type of object. Density was measured on the following levels: $1 \mathrm{~mm}, 5 \mathrm{~mm}$, and $10 \mathrm{~mm}$, for the average duration of cable car journey from the initial station to the end station of approximately 2 minutes. Defining the vertical and horizontal scope of laser scanner measurement turned out to be of significance too. The vertical scope covered the carry- 
ing lines and the drive lines in standstill, after the departure of the wagon from the station, lowering the pull lines under the load, the arm of the wagon, and the cabin. As a result, it was assumed that it is possible to obtain the fragment of a rope in standstill, bending the line during travel, as well as a small fragment of the arm and the cable car wagon, whereas the horizontal scope was defined by means of trial-and-error method, and it encompassed the fragment of the ropes that the scanner was able to measure in the course of a single journey of the cable car from one station to the other. The time of measurement, the density of points, and the vertical and horizontal scopes had to be specified on the basis of several dozen of attempts. These proved to be time-consuming and dependent on the journeys of variably loaded wagons - as the cable car operates irregularly - depending on the volume of persons using it at a given point in time. All the above factors needed to interact with one another in order to obtain feasible results.

According to the authors, the density of points defined at the level of $5 \mathrm{~mm}$ proved to be the most adequately reflecting the tested object. The application of density at the level of $10 \mathrm{~mm}$ turned out to be insufficient - the carrying lines were relatively thin from the distance of the stand, while obtaining density at the level of $1 \mathrm{~mm}$ proved to be too time-consuming and prevented the measurement of the given fragment of the cable line in the course of which the passing wagons would be visible.

\section{Test results}

After all preparations, two measurements by TLS were made in various weather conditions (windless and variable - rain and wind) on the same day, in the time interval of about 3 hours. Two clouds of points were obtained from the measurements, which were combined in Cyclone and presented in Figure 5. As indicated in Figure 5, the measurement included fragments of the support line, the arm of the gondola, and the gondola itself. Only the point cloud measured during windless conditions was accepted for analysis. The second point cloud (variable atmospheric conditions) will be analysed in another study and at this stage is only visual information.

Subsequent journeys of the wagons are clearly visible in Figure 6 below. It presents the entire scope of measurements for two wagons moving along two carrying lines in the course of a single measurement session. Each journey (assumed as shape of letter $\mathrm{V}$ ) in both directions was realized from one station to the other, at different wagon loads. The point cloud presents three complete journeys of both wagons and one with the missing point data.

The entire measurement scope (cycle) was presented in Figure 6. It is a processed point cloud.

The measurement of this point cloud lasted over 26 minutes. It covered four gondola rides (in both directions), which lasted approx. 2 minutes each and three breaks in the ride ( 4 minutes each). The break is the average waiting time for the start of the journey. The measurement was started and completed while the cable car was stationary. The average speed of the cable car during each of the journeys was $3.5 \mathrm{~m} / \mathrm{s}$. Supporting rope diameter was $24 \mathrm{~mm}$. 


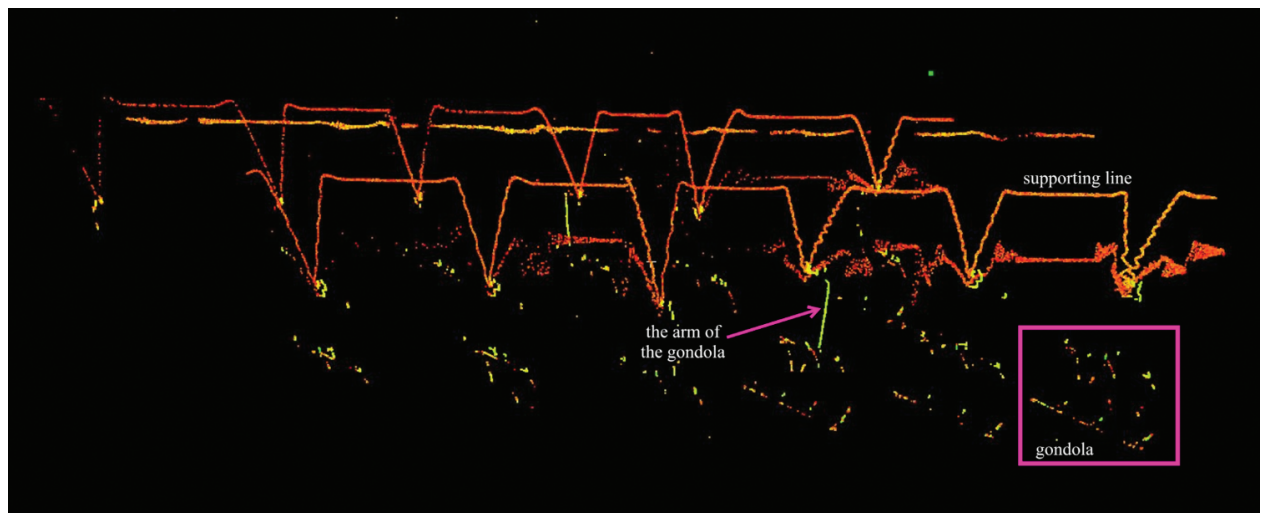

Source: Authors' own study

Fig. 5. Combined unprocessed point clouds (without filtration)

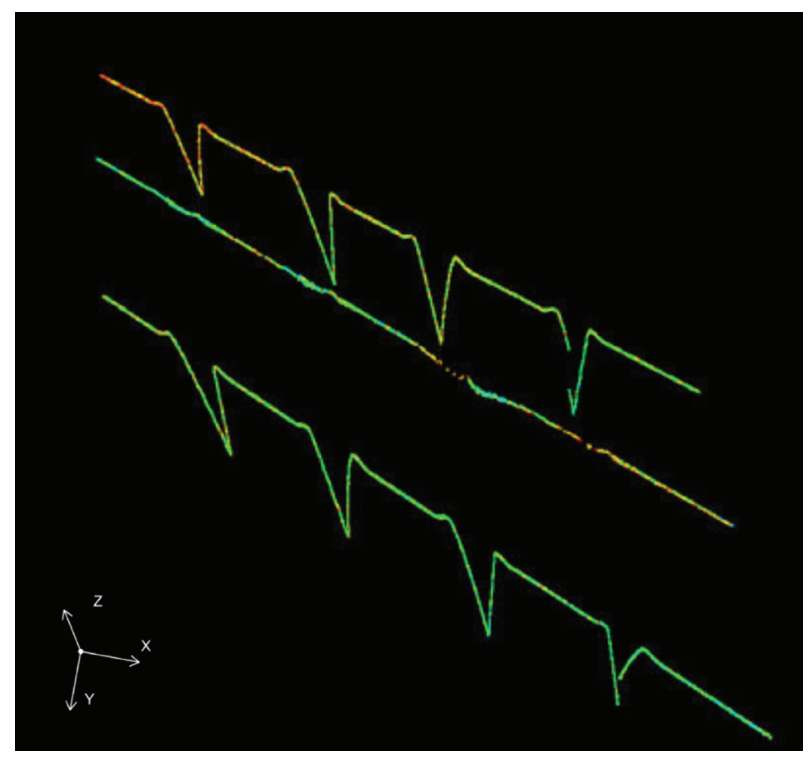

Source: Authors' own study

Fig. 6. The scope covered by the measurement from the laser scanner

The point cloud was adjusted to the National Geodetic Coordinate System ETRS89 / Poland CS2000 zones 5-8 (measurement performed in zone 6) and height arrangement Kronstadt (designation: PL-KRON86-NH), post machining and filtering of data within the Leica Cyclone program for the processing of point clouds. After manual filtration, 86767 points remained. The points from Total Station measurement (numbered and marked with yellow reference marks) were included into the cloud for 
the purpose of comparison and adjustment of measurement results from these two instruments (Fig. 7).

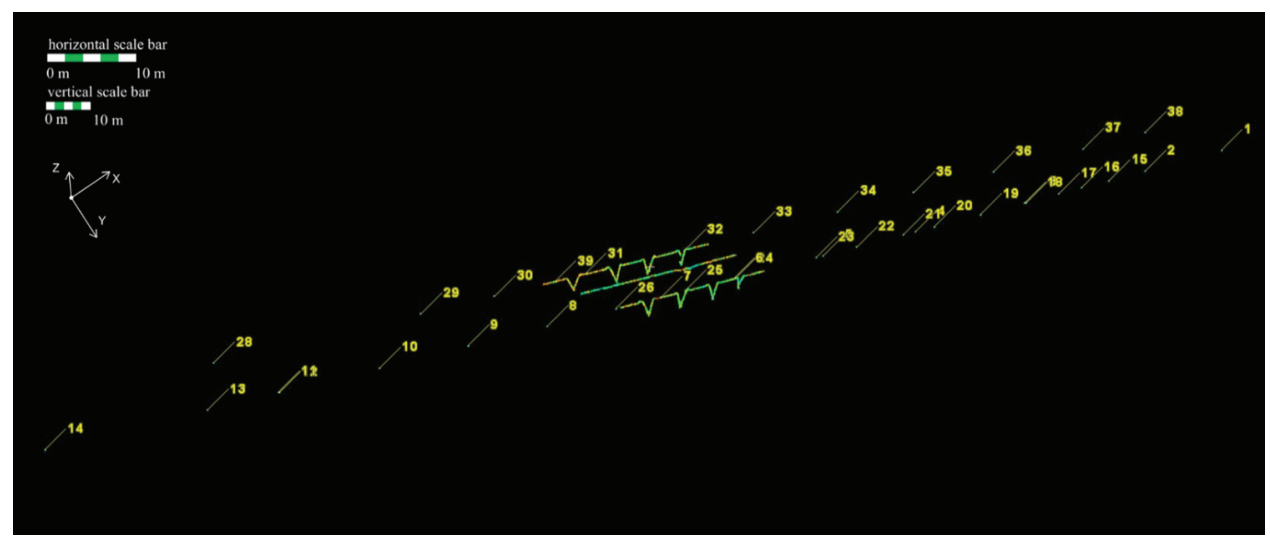

Source: Authors' own study

Fig. 7. Combined Total Station measurement with the fragment of the point cloud from the scanner (central part of the Figure)

As illustrated with the example of one of the carrying ropes (Fig. 8) discrepancies between the point cloud and the TS measurements were revealed. The values for individual points (No. 6, 7, 24, 25, 26, 31, 32, 39 - Fig. 7) are respectively: $-19,+33,-17$, $+21,+15,-23,-9,-27$ (values given in $\mathrm{mm}$ ). The discrepancies were measured within the program while the Figures presenting the differences were placed below. Figure 8 shows the east fragment of the carrying rope on which point No. 7 is visible as well as the said rope and the point in magnification (red rectangle).

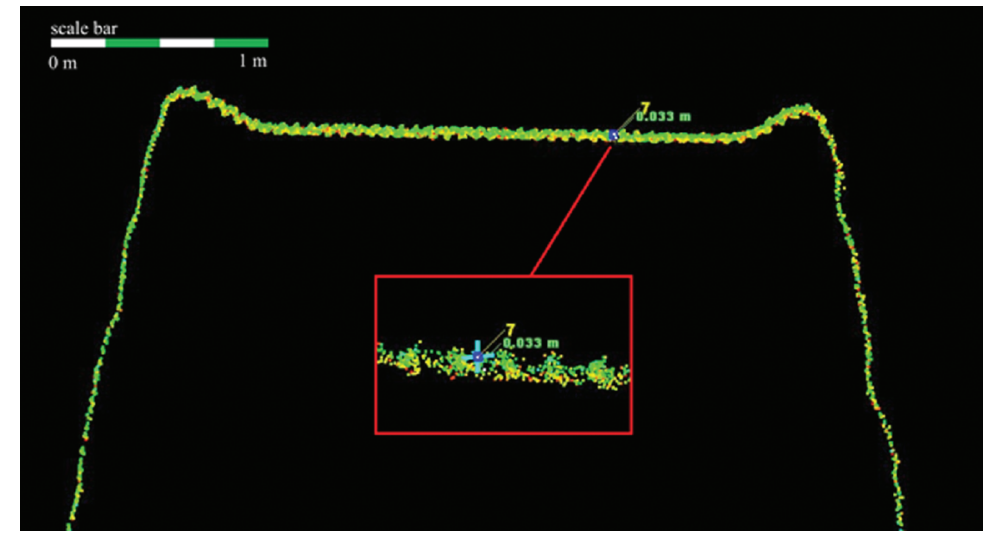

Source: Authors' own study

Fig. 8. Disparities between observations via Total Station and the point cloud from the scanner 
With regard to the point cloud obtained from the laser scanner and the effects related to it, this has been presented on the subsequent Figures. Figure 9 presents a cut-out fragment of cloud, one journey - from one station to the other - of a single wagon. It presents a place - optically observed during measurements - of the largest bending of the ropes, and the lowest position of the wagon towards the water table of the river (in the adopted measuring range). Attempting to measure the lowest position of the gondola is problematic; a better solution might be to analyse the trajectory of the gondola on the basis of the measured transit passage and determine all parameters of motion.

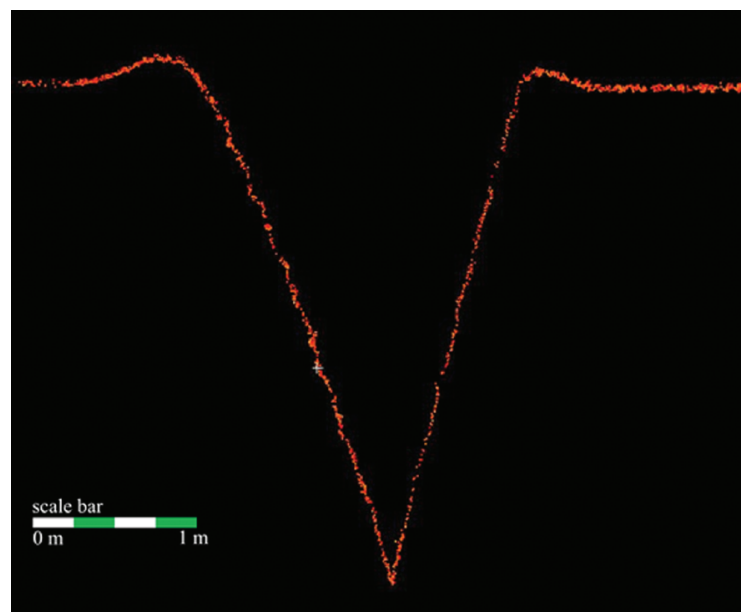

Source: Authors' own study

Fig. 9. Fragment of point cloud presenting the course and behaviour of the carrying cable during the journey of a wagon through the scope covered by the scanning

The shape of the rope, registered by means of measurements, resembles letter V. Initially a slight elevation occurs, and subsequently the carrying cable lowers under the impact of the dynamic load of the moving wagon. In the lower part of the letter $\mathrm{V}$, a point of contraflexure is located, which reflects the change - the lifting of the line upwards (Fig. 10).

In order to verify numerically the values of change in the location of the rope during movement of the cable car, calculations were carried out. For the rope fragment (data set) shown on Figure 9, we calculated the coordinates of rope points (local reference system) on the system of coordinates related to the direction of the rope, obtained from the measurements. First of all, straight line compliant with the method of least squares was entered in the XY plane. Subsequently, transformation of points (rotation) was applied on the basis of the obtained equation for the straight line. As a result of this action, the measured coordinates $\mathrm{XYZ}$ were replaced with coordinates DVZ. Coordinate $\mathrm{D}$ is the present measure along the rope. Coordinate V represents the distance in horizontal plane of the point from the designated axis. Coordinate 
$\mathrm{Z}$ remained unchanged. One ought to bear in mind that in relation to the one-sided placement of measurement stands towards the rope (see Fig. 4), the straight line, which was marked on XY plane, did not coincide with the axis of the rope. Figure 11 presents the result of adjusting the straight line to the set of measurement points of the rope.

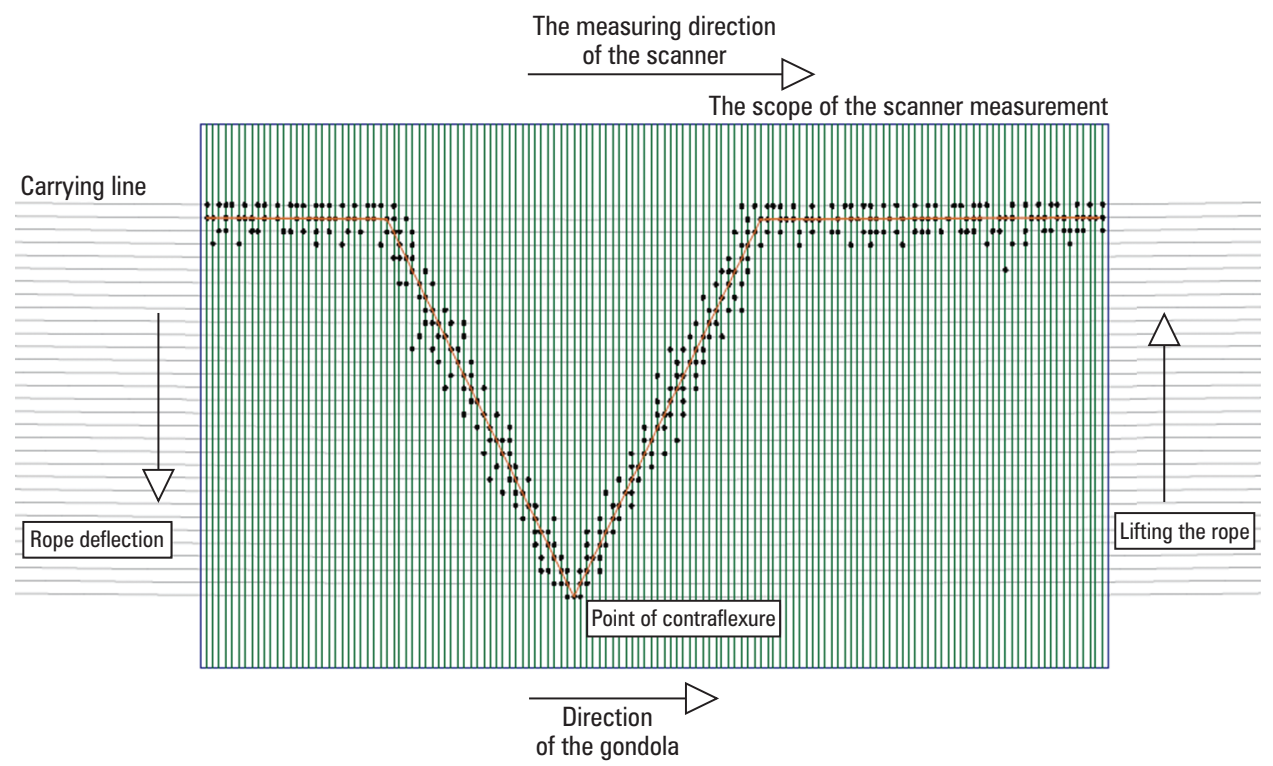

Source: Authors' own study

Fig. 10. Diagram of the shape of the supporting rope, determined in the measuring range by the passage of the cable car wagon between the stations

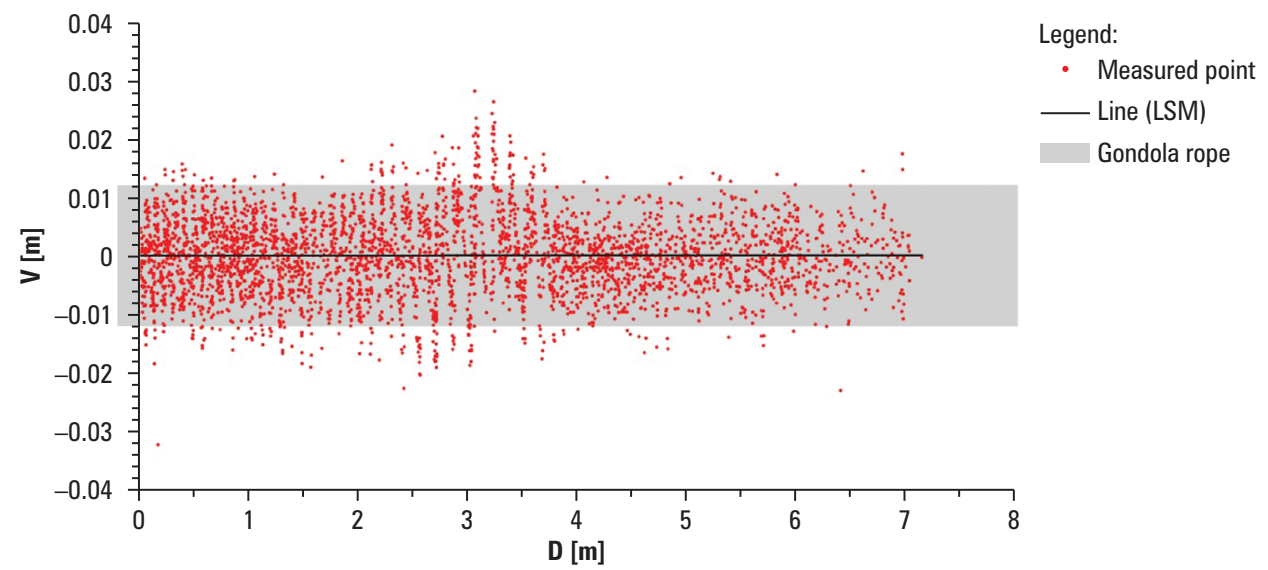

Fig. 11. Result of the transformation of the rope into a straight line in accordance with the Least Square Method 
Subsequently, a diagram of changes in the location of the height of the rope in the function of its length to the journey of the gondola cable car was elaborated. The result was presented in Figure 12.

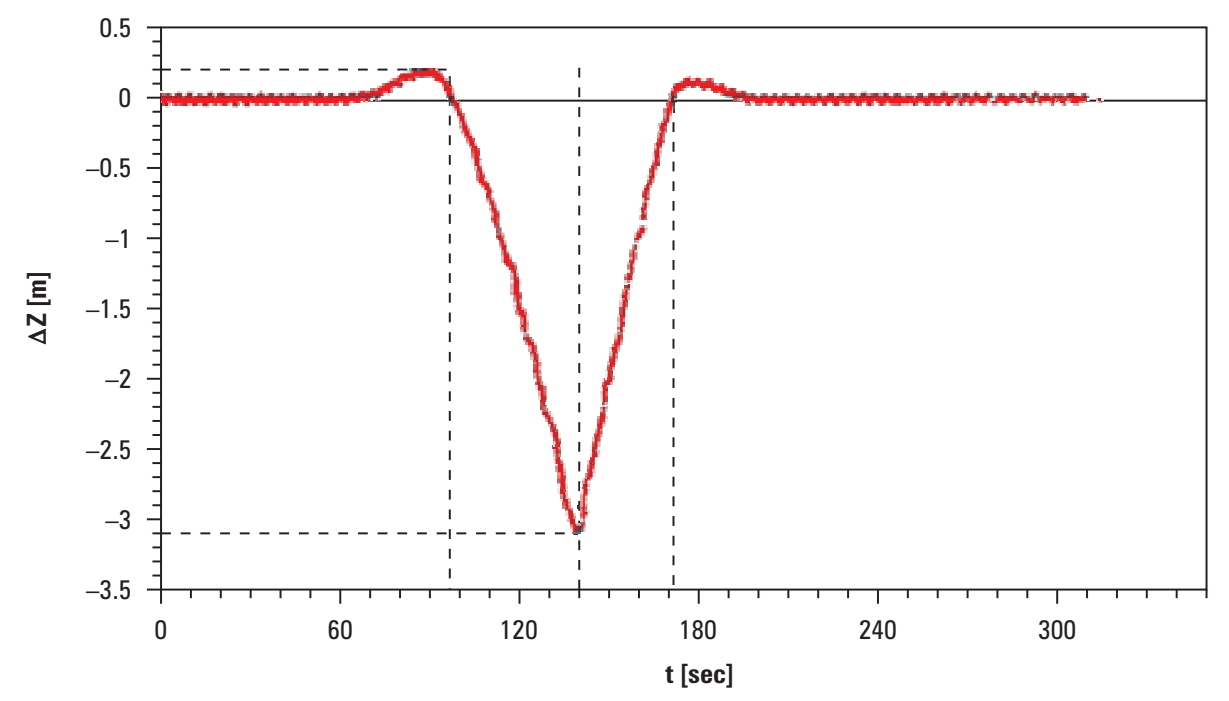

Fig. 12. Vertical change of the location of the carrying rope in the course of gondola movement in function of time

As can be observed in the above Figure, the movement of the gondola causes significant changes in the shape of the carrying cable. Along with the approaching gondola, the initially light elevation of points of the rope by approx. $0.2 \mathrm{~m}$ occurs. Then, the rope drops down by approx. $3.1 \mathrm{~m}$ in order to subsequently rise above the static position and drop yet again to $0.0 \mathrm{~m}$. The obtained effect of the asymmetry of shape (inclination of the changes to the height of rope) is indeed unique. When the gondola enters the measurement area, the effect of lowering is registered by means of the measurement over approx. 42 seconds, whilst the rising of the gondola occurs within the section of approx. 31 seconds. This asymmetry will be subjected to detailed tests in the future, similarly to the effect of "uplift" of the rope.

\section{Conclusions}

The basic goal of the measurement was to determine the geometry of the moving object using the TLS method. The results obtained during the measurement are very interesting in the aspect of the description of gondola motion parameters.

The tests we carried out covered the basic and control measurement of bending of the carrying ropes in kinematic state, upon different loads. The subsequent step was to compare the results of observations from Total Station and Terrestrial Laser Scanning. The tests indicated the possibility of grasping changes in geometry 
via the TLS method in the course of constant vibration of the pull lines and during the movement of gondolas, however upon strictly specified measurement conditions - density of points and scope of measurement. Differences in observations between the scanner and the Total Station reached approx. $\pm 30 \mathrm{~mm}$ along the entire measurement section, which is considered by the authors as a very good result for the applied measurement method. The results of measurements and observations proved that laser scanning could serve as a tool in obtaining changes in the location - not only of single points on carrying lines but also of multiple points of drive lines and carrying lines. The advantage of this method is the fact that it may be applied during the on-going operation of the cable car. Laser scanning provides a broad spectrum of possibilities for the analysis and use of point measurement data - measurements of infrastructure elements, creation of sections, numerical area models, designing, monitoring of the state of infrastructure, and detection of dangers. The additional advantage of laser scanning is a very detailed and, moreover, precise registration of the condition of infrastructure in various moments of time, as well as its significant impact on the reduction of costs. Multitude of points obtained in the form of point clouds in case of the "Polinka" cable car may serve not only for the assessment of the cable car bending but also for its inventory taking, assessment of technical state of the pull lines or elimination of the threat of construction disasters.

The obtained results are very promising. The shape of the carrying rope in the course of movement of the gondola cable car will be subjected to further analyses, whereas the results we already obtained ought to allow for detailing the dynamic shape of the object and the construction of a theoretical model.

\section{References}

Abmayr T., Härtl F., Reinköster M., Fröhlich C. 2012. Terrestrial laser scanning - applications in cultural heritage conservation and civil engineering. International Society for Photogrammetry and Remote Sensing. isprs.org/proceedings/XXXVI/5-W17/

Barbarella M., Fiani M., Lugli A. 2013. Landslide monitoring using multitemporal terrestrial laser scanning for ground displacement analysis. Geomatics, Natural Hazards and Risk, 4, $1-21$.

Barbarella M., Fiani M., Lugli A. 2017. Uncertainty in Terrestrial Laser Scanner Surveys of Landslides. Remote Sensing of Environment, 9, 113.

Bazarnik M. 2016. Application possibilities of 3D terrestrial laser scanning in the reclamation of mining areas. Bulletin of the Mineral and Energy Economy Research Institute of the Polish Academy of Sciences, 94, 149-159.

Bernat M., Byzdra A., Chmielecki M., Laskowski P., Orzechowski J., Rzepa S., Szulwic J., Ziółkowski P. 2016. Zastosowanie naziemnego skaningu laserowego i przetwarzanie danych: inwentaryzacja i inspekcja obiektów budowlanych. I-NET.PL

Buchroithner M.F., Gaisecker D.T., Österreich H. 2009. Modeling and Visualization Using Laser Scanner in Documentation of Cultural Heritage Photogrammetrie, Fernerkundung, Geoinformation, 4, 329-339.

Buczek M., Paszek M., Szafarczyk A. 2018. Application of Laser Scanning for Creating Geological Documentation E3S Web of Conferences 35, 04001 
Choi S.W., Kim B.R., Lee H.M., Kim Y., Park H.S. 2013. A deformed shape monitoring model for building structures based on a 2D laser scanner. Sensors, 13, 6746-6758.

Corso J., Roca J., Buill F. 2017. Geometric Analysis on Stone Façades with Terrestrial Laser Scanner Technology. Geosciences, 7, 103.

El-Omari S., Moselhi O. 2008. Integrating 3D laser scanning and photogrammetry for progress measurement of construction work. Automation in Construction, 18(1), 1-9.

Galeazzi F., Moyes H., Aldenderfer M. 2014. Defining Best 3D Practices in Archaeology: Comparing Laser Scanning and Dense Stereo Matching Techniques for 3D Intrasite Data Recording, Advances in Archaeological Practice, 2, 4, 353-365.

Gawronek P., Kumosiński W., Kwinta A., Patykowski G., Zygmunt M. 2016. Zastosowanie naziemnego skaningu laserowego w badaniu górniczych obiektów inżynierskich (The application of terrestrial laser scanning in the study of mining engineering objects). Bezpieczeństwo Pracy i Ochrona Środowiska w Górnictwie, 2(258).

Ghuffar S., Székely B., Roncat A., Pfeifer N. 2013. Landslide displacement monitoring using 3D range flow on airborne and terrestrial LiDAR data. Remote Sensing, 5, 2720-2745

Gikas V. 2012. Three-Dimensional Laser Scanning for Geometry Documentation and Construction Management of Highway. Sensors, 12, 11249-11270.

Gordon S.J., Lichti D.D. 2007. Modeling terrestrial laser scanner data for precise structural deformation measurement. Journal of Surveying Engineering, 133, 72-80.

Herráez J., Martínez J.C., Coll E., Martín M.T., Rodríguez J. 2016. 3D modeling by means of videogrammetry and laser scanners for reverse engineering. Measurement, 87, 216-227.

https://pl.wikipedia.org/wiki/Kolej_gondolowa_„Polinka”_we_Wrocławiu

https://visitwroclaw.eu/miejsce/polinka-wroclaw

Jackson T., Shenkin A., Wellpott A., Calders K., Origo N., Disney M., Burt A., Raumonen P., Gardiner B., Herold M., Fourcaud T., Malhi Y. 2019. Finite element analysis of trees in the wind based on terrestrial laser scanning data. Agricultural and Forest Meteorology, 265, 137-144.

Janowski A., Nagrodzka-Godycka K., Szulwic J., Ziolkowski P. 2016. Remote sensing and photogrammetry techniques in diagnostics of concrete structures. Computers and Concrete, 18 , 3, 405-420.

Jo Y.H., Hong S. 2019. Three-Dimensional Digital Documentation of Cultural Heritage Site Based on the Convergence of Terrestrial Laser Scanning and Unmanned Aerial Vehicle Photogrammetry. ISPRS Int. J. Geo-Inf., 8.

Jones R.R., Kokkalas S., McCaffrey K.J.W. 2009. Quantitative analysis and visualization of nonplanar fault surfaces using terrestrial laser scanning (LIDAR). The Arkitsa fault, central Greece, as a case study. Geosphere, 5, 465-482.

Kamiński W., Bojarowski K., Dumalski A., Mroczkowski K., Trystuła J. 2008. Possibilities of using laser scanner Scanstation from Leica to research deformation of building structures. Technical transactions, Wydawnictwo Politechniki Krakowskiej, 2-Ś.

Klimkowska H., Wróbel A. 2006. Uwagi o wykorzystaniu tachimetrów bezlustrowych w inwentaryzacji architektonicznej (Remarks on the use of reflectorless total stations in architectural inventory). Archives of Photogrammetry, Cartography and Remote Sensing, 16.

Kraszewski B. 2012. Utilization of terrestial laser scanning for office inventory. Archives of Photogrammetry, Cartography and Remote Sensing, 23, 187-196.

Kwinta A., Ważydrąg K., Zygmunt M. 2018. Analysis of power lines span geometry based on TLS measurements. E3S Web of Conferences, 55, 00013.

Lenda G. 2005. Zastosowanie funkcji sklejanych w zautomatyzowanym procesie geodezyjnej kontroli kształtu powierzchni obiektów budowlanych (Application of glued functions in the 
automated geodetic process of controlling the shape of the surface of buildings). Doctoral dissertation, AGH Kraków.

Mill T., Ellmann A. 2019. Assessment of a long-normal uncertainties for application to terrestrial laser scanning surveys of engineering structures. Survey Review, 51(364), 1-16.

Olsen M.J., Kuester F., Chang B.J., Hutchinson T.C. 2010. Terrestrial laser scanning-based structural damage assessment. Journal of Computing in Civil Engineering, 24(3), 264-272.

The Ordinance of the Minister of Transport and Maritime Economy on the technical conditions to be met by railway structures and their location. Dz. U. 1998, Nr 151, poz. 987.

Quagliarini E., Clini P., Ripanti M. 2017. Fast, low cost and safe methodology for the assessment of the state of conservation of historical buildings from 3D laser scanning: The case study of Santa Maria in Portonovo (Italy). Journal of Cultural Heritage, 24, 175-183.

Pilecka E., Manterys T. 2013. Badania przemieszczeń osuwiska w Mogilanach naziemnym skanerem laserowym (Investigation of dislocation of the landslide in Mogilany with a terrestrial laser scanner). Zeszyty Naukowe Instytutu Gospodarki Surowcami Mineralnymi i Energią, Polskiej Akademii Nauk, 84.

Pilecki R. 2012. The use of ground-based laser scanner. Technical transactions. Wydawnictwo Politechniki Krakowskiej, 26, 109.

Roca-Pardiñas J., Ordóñez C., Cabo C., Menéndez-Díaz A. 2017. Assessing planar asymmetries in shipbuilding from point clouds Measurement. Journal of the International Measurement Confederation, 100, 252-261.

Rüther H., Held Ch., Bhurtha R., Schröder R., Wessels S. 2013. Challenges in Heritage Documentation with Terrestrial Laser Scanning. European Scientific Journal, 9, 24.

Slob S., Hack R. 2004. 3D Terrestrial Laser Scanning as a New Field Measurement and Monitoring Technique, Engineering Geology for Infrastructure Planning in Europe Lecture Notes in Earth Sciences, 104, 179-189.

Soudarissanane S., Lindenbergh R., Gorte B. 2008. Reducing the error in terrestrial laser scanning by optimizing the measurement set-up. Proceedings of International Archives of Photogrammetry, Remote Sensing and Spatial Information Sciences, Beijing, China, XXXVII (Part B5), 615-620.

Szafarczyk A., Gawałkiewicz R. 2018. Defining the Cubature Changes of Historic St. Kinga Chamber in Bochnia Salt Mine, Using Laser Scanning Technology. E3S Web of Conferences, $35,04006$.

Tong X., Liu X., Chen P., Liu S., Luan K., Li L., Liu S., Liu X., Xie H., Jin Y., Hong Z. 2015. Integration of UAV-Based Photogrammetry and Terrestrial Laser Scanning for the ThreeDimensional Mapping and Monitoring of Open-Pit Mine Areas. Remote Sensing of Environment, 7, 6635-6662.

Uchański Ł., Soerensen L. 2010. Technology of terrestrial laser scanning in problems of reverse engineering and dynamic process analysis. Archiwum Fotogrametrii, Kartografii i Teledetekcji, 21, 415-424.

Xu X., Zhao X., Yang H., Neumann I. 2017. Tls-based feature extraction and 3d modeling for arch structures. Journal of Sensors, article 9124254,

Zaczek-Peplinska J., Kowalska M.E. 2016. Terrestrial laser scanning in monitoring hydrotechnical objects. Journal of Ecological Engineering, 17, 4, 120-128. 
Dr hab. inż. Andrzej Kwinta, prof. UR University of Agriculture in Krakow Department of Geodesy

30-149 Kraków, ul. Balicka 253a

e-mail: andrzej.kwinta@urk.edu.pl

ORCID: 0000-0002-2003-7703

Dr inż. Robert Gradka

Wrocław University of Technology

Department of Geodesy and Geoinformatics

50-421 Wrocław, ul. Na Grobli 15

e-mail: robert.gradka@pwr.edu.pl

ORCID: 0000-0002-0213-8180 